\title{
Народне књижнице и читаонице као облик јавног библиотекарства у Србији од 1918. до 1941. године
}

Биљана М. Ђурашиновић

biljana.djurasinovic@gmail.com

\begin{abstract}
Сажетак
Циљ текста је да се опише рад народних књижница и читаоница у Србији у периоду од 1918. до 1941. године. У уводном делу представљени су облици јавног библиотекарства у Србији између два светска рата, са посебним освртом на разлике између појединих типова установа. Први део рада посвећен је делатности народних књижница и читаоница у посматраном периоду. У другом делу описан је рад Шабачке народне књижнице и читаонице, која је радила између 1928. и 1941. године, а била је најбоље организована установа овог типа на територији Србије. Последњи део заснива се на дефинисању делокруга рада Савеза народних књижница и читаоница - организацији која је требало да окупи све народне књижнице и читаонице на територији Краљевине. Својом делатношћу народне књижнице и читаонице допринеле су разноврсности јавног библиотекарства у периоду између два светска рата и побољшању општих културних прилика на територији Србије.
\end{abstract}

Кључне речи: народне књижнице и читаонице, јавне библиотеке, читалишта, правила народних књижница и читаоница, Шабачка народна књижница и читаоница, јавно библиотекарство, Србија 1918-1941, Савез народних књижница и читаоница

Увод

Јавно библиотекарство у Србији између два светска рата засновано је на истовременом постојању читалишта, народних књижница и читаоница и јавних библиотека. ${ }^{1}$ Сви облици јавног библиотекарства имали су карактеристичне елементе, као што су доступност публикација, организација фондова и корисници на основу којих се одређују као посебни типови установа. Основна разлика у њиховом деловању може се повући између народних књижница и читаоница и јавних библиотека. Обе су омогућавале општу доступност публикација свим слојевима друштва, али је финансирање њихове делатности било другачије. Делатност народних књижница и читаоница и читалишта је била истоветна, што се може закључити на основу поређења доступних података која су обухватала организовање културно-образовних програма и начин коришћења.

У штампаним изворима делатност читалишта се, у већини случајева, повезује са потоњим јавним библиотекама, што се документовано може потврдити само за Библиотеку града Београда и Народну библиотеку у Крагујевцу. У случају осталих јавних библиотека требало би урадити детаљно истраживање свих доступних извора (првенствено архивске грађе) и на основу њих формулисати закључке о утицају и делатности појединачних установа. У вези са поменутим проблемом, пажњу би требало посветити свим облицима јавног библиотекарства

\footnotetext{
1 Рад је настао на основу истраживања спроведеног у оквиру докторске дисертације „Јавне библиотеке у Србији 1919-1941: практични и теоријски домети" која је у процесу израде.
} 
Ђурашиновић Б. „Народне књижнице и читаонице као облик јавног библиотекарства у Србији од 1918. до 1941. године”, 62-70

међуратног периода јер постоји могућност да су, након завршетка Другог светског рата, њихови фондови постали део новостворених народних библиотека. За народне књижнице и читаонице сачувана је обимна архивска грађа, ${ }^{2}$ у оквиру које се на основу правила и извештаја о раду одређује структура, обим делатности и значај у развоју јавног библиотекарства на територији Србије од 1918. до 1941. године.

\section{Народне књижнице и читаонице као облик јавног библиотекарства и делатност између два светска рата}

Према речима Жељка Вучковића, ${ }^{4}$ народне књижнице и читаонице представљале су установе у којима су се преплитале и допуњавале библиотечке и читалишне функције, а, поред библиотечке делатности, бавиле су се и различитим пословима од значаја за културу, просвету и забаву. Њихов рад био је под надзором Одељења за народно просвећивање Министарства просвете Краљевине Југославије, ${ }^{5}$ а фондови су најчешће служили као допуна образовању након завршене основне школе.

Осниване су приватном иницијативом, али је њихова правила одобравало Министарство просвете (уз сагласност Министарства унутрашњих послова), које је прописало и образац са подацима које би требало да садржи. У периоду од 1919. до 1941. године на територији Србије постојало је 1218 читаоница и народних књижница и читаоница, ${ }^{6}$ чији је рад био усаглашен са правилима која је прописивало надлежно министарство. На основу архивске грађе може се утврдити да је највећи број народних књижница и читаоница осниван од 1929. до 1935. године, док у периоду од 1937. до Другог светског рата долази до стагнације и затварања овог типа установа.

Поред народних књижница и читаоница, између два светска рата на територији Србије, као облик јавног библиотекарства, постојале су и јавне библиотеке. Основна разлика између њих била је у начину финансирања. Јавне библиотеке су се у већини случајева финансирале из посебног кредита општине или Краљевине, док су се народне књижнице и читаонице

\footnotetext{
2 Чува се у Архиву Југославије, као део фонда Министарства просвете Краљевине Југославије који се односи на народне књижнице и читонице (А - 66, 296-309 Народне књижнице и читаонице; А - 66, 472, 745 Народне књижнице и читаонице (Б-Ж); А - 66, 2278,2151 Народне књижнице и читаонице (А-Бољ); 66, 2279, 2151 Народне књижнице и читаонице (Бос-Го); А - 66, 2280, 2151 Народне књижнице и читаонице (Гр-Кор); А - 66, 2281, 2151 Народне књижнице и читаонице (Кос-Л); А - 66, 2282, 2151 Народне књижнице и читаонице (Љ-Пе); А - 66, 2283, 2151 Народне књижнице и читаонице (Пи-Ра); А - 66, 2284, 2151 Народне књижнице и читаонице (Ре-Ср); А - 66, 2285, 2151 Народне књижнице и читаонице (СТ-Т); А - 66, 2286, 2151 Народне књижнице и читаонице (У-В); А - 66, 2287, 2151 Народне књижнице и читаонице (3-Ж); А - 66, 2498, 2318 Народне књижнице и читаонице (А-Бе); А - 66, 2499, 2318 Народне књижнице и читаонице (Би-Ц); А - 66, 2500, 2318 Народне књижнице и читаонице (Ч-Ф); А - 66, 2501, 2318 Народне књижнице и читаонице (Г-И); А - 66, 2502, 2318 Народне књижнице и читаонице (J-Ко); А - 66, 2503, 2318 Народне књижнице и читаонице (Кр-Ку); А - 66, 2504, 2318 Народне књижнице и читаонице (Л-Ни); 66, 2505, 2318 Народне књижнице и читаонице (Но-Пи); А - 66, 2506, 2318 Народне књижнице и читаонице (Пљ-Пт); А - 66, 2507, 2318 Народне књижнице и читаонице (Р-См); А - 66, 2508, 2318 Народне књижнице и читаонице (Со-Ст); А - 66, 2509, 2318 Народне књижнице и читаонице (Су-Ти); А - 66, 2510, 2318 Народне књижнице и читаонице (То-У); А - 66, 2511, 2318 Народне књижнице и читаонице (Ва-Влад); А - 66, 2512, 2318 Народне књижнице и читаонице (Влас-Ж); А - 66, 262, 503 Зборник расписа Министарства просвете о раду на народном просвећивању и Правила народних књижница и читаоница).

${ }^{3}$ Истраживање структуре и обима делатности јавних библиотека међуратног периода (осим података који су неопходни за дефинисање разлика између народних књижница и читаоница и јавних библиотека) није од значаја за овај рад, па му у њему неће бити посвећена посебна пажња.

${ }^{4}$ Жељко Вучковић, Јавне библиошеке и јавно знање (Нови Сад: Библиотека Матице српске; Футура публикација, 2003 ), 100.

5 У периоду између два светска рата усвојене су три уредбе о уређењу Министарства просвете: 1919, 1929. и 1937. године. Првом уредбом постојало је Одељење за основну наставу и народно просвећивање и било је део Општег одељења; Другом и трећом уредбом као Одсек, односно Одељење за народно просвећивање, које се, у зависности од структурних промена, и даље налазило у оквиру појединих одсека или је било самостално.

${ }_{6}^{6}$ У овај број су укључене читаонице (које у себи садрже називе српска, грађанска, словачка, хрватска, мађарска) и народне књижнице и читаонице које су имале правила која су била у складу са прописима Министарства. Задружне, ратарске, пољопривредне и рударске књижнице и читаонице такође су имале Правила која су била у складу са одредбама Министарства, али се оне не могу сматрати обликом јавног библиотекарства, пре свега, јер су функционисале као саставни део појединих удружења (Пољопривредног, Задружног и Рударског), а и садржај фондова био је прилагођен корисницима којима су биле потребне књиге из тих фондова (пољопривредници, рудари итд).
} 
издржавале средствима чланова. На основу доступне грађе, могуће је пронаћи податке и о периодичном издвајању средстава за поједине народне књижнице и читаонице из буџета Краљевине, али им то није био основни извор финансирања. Набавка публикација за јавне библиотеке вршила се поклоном, разменом или куповином из општинског буџета, док су публикације за народне књижнице и читаонице најчешће прослеђиване из слагалишта књига Министарства просвете Краљевине Југославије, које их је набављало куповином или откупом од правних или физичких лица.

Правила за народне књижнице и читаонице усвојена су 1920. (употпуњена 1924. и 1931. године). ${ }^{7}$ У оквиру њих 8 били су дефинисани: име; циљ - задатак; средства; фонд за подизање дома народне књижнице и читаонице; врсте чланова и њихова права и дужности; управни одбор - његова права и дужности, као и дужности председника, потпредседника, секретара, благајника и књижничара; права и дужности надзорног одбора и врста скупштине, делокруг њеног рада, време и начин сазивања. Одлуке Министарства просвете биле су обавезујуће за управни, надзорни одбор и скупштину одређене народне књижнице и читаонице, а на крају године, управљачке структуре подносиле су му извештај о раду и примерак годишњег рачуна. Сва преписка са државним властима вршила се преко среског начелства надлежног за одређено подручје. На овај начин институције Краљевине биле су повезане са службама локалне самоуправе, што је омогућило координацију њиховог деловања.

У раду народних књижница и читаоница коришћени су и посебни обрасци које је прописало Министарство просвете. Они су обухватали: списак чланова народних књижница и читаоница (образац бр. 7); списак књига, часописа и новина (обрасци бр. 1, 2, 3); књига наплате чланских улога (образац бр. 8); списак намештаја - ствари (образац бр. 4); дневник примања и издавања новца (образац бр. 5); дневник о позајмљеним књигама (образац бр. 6). Поред ових образаца, Одсек за народно просвећивање требало је да одреди и оне на којима би се бележиле седељке, али на основу доступне грађе није било могуће утврдити да ли су и прописани. Овакав начин пописа фондова народних књижница и читаоница, иако му недостаје вођење каталога библиотечке грађе, омогућавао је основну евиденцију, а на основу дневника позајмице могао се извршити увид у коришћење монографских и серијских публикација.

Од свих народних књижница и читаоница на подручју Србије, према начину рада (организација фондова, доступност публикација, корисници) и делатношћу у оквиру локалне заједнице и Краљевине може се издвојити Шабачка народна књижница и читаоница.

\section{Рад Шабачке народне књижнице и читаонице}

Идеја о јавној доступности књиге и библиотека свој рудиментарни организациони образац остварује у раду читалишта. У Шапцу она се може пратити од 1847. године, када је, након дозволе Министарства просвете и Министарства унутрашњих послова, основано читалиште. Документовано се може тврдити да је постојало до 1880. године, а након тога „уместо читаонице, чешће се помиње Шабачко певачко друштво, као и стално позориште основано у Шапцу средином 1896. године." ${ }^{\prime \prime}$

Период између два светска рата обележен је радом Шабачке народне књижнице и читаонице, која је своју делатност обављала од 1928. до 1941. године. „У једној од учионица старе гимназијске зграде, у којој је Читалиште већ боравило, договорено је 3. јануара 1928. године да се обнови Читаоница. Млађи заговорници ове идеје ишли су по граду тражећи потписе

\footnotetext{
${ }^{7}$ На основу доступне грађе није могуће прецизно утврдити у чему су се састојале допуне.

${ }^{8}$ А $-66,262,503$ Фонд Министарства просвете Краљевине Југославије, Зборник расписа Министарства просвете о раду на на-

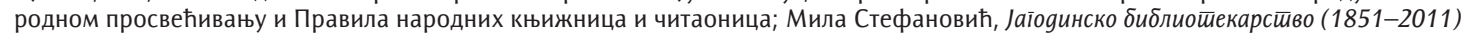
(Јагодина: Народна библиотека „Радислав Никчевић”, 2011), 123.

9 Десанка Стаматовић, Чишалишйа у Србији у XIX веку (Панчево: Градска библиотека, 2011), 202.
} 
Ђурашиновић Б. „Народне књижнице и читаонице као облик јавног библиотекарства у Србији од 1918. до 1941. године”, 62-70

суграђана на предложена Правила Читаонице. Министарство просвете 21. јануара 1928. године одобрило је Правила, а 7. фебруара одржана је Прва скупштина Шабачке народне књижнице и читаонице." ${ }^{10}$ Установа је наследила фондове Грађанске читаонице и Катастарске секције. Највећим делом се издржавала из приватних средстава (чланским улозима у износу од 5 и 10 динара), а набавка публикација углавном се вршила из средстава појединаца и приватних установа. Од државних органа периодично је примала средства од Краљевине, бановине и општине. У првих пет година рада није примала новчану помоћ од Министарства просвете, да би јој у оквиру буџета за 1933/34. годину било одобрено 5000 динара помоћи. „Карактеристично је да је у 1934 години примљено наиме субвенције од министарства просвете и бановине 17.500 динара." 11

Шабачка народна књижница и читаоница била је организована као установа у којој је постојало неколико појединачних одељења: библиотека и читаоница, Народни универзитет и музеј. У оквиру ње покренуто је, крајем 1931, и оснивање одбора за подизање споменика Вуку Караџићу у Тршићу и Лозници. Године 1933. обновљено је Вуково огњиште, а следеће године прикупљена су средства за подизање Дома културе у Лозници. Исте године основан је и музеј.

Тридесетих година 20. века у оквиру Шабачке народне књижнице и читаонице организоване су позоришне и музичке представе, а одржавана су и предавања свих значајнијих представника интелектуалне и културне елите Краљевине Југославије (нпр. Ивана Ђаје (1884-1957), ${ }^{12}$ Тодора Манојловића (1883-1968), ${ }^{13}$ Милоша Московљевића (1884-1968), ${ }^{14}$ Владимира Дворниковића (1888-1956), ${ }^{15}$ Станислава Винавера (1891-1955), ${ }^{16}$ Авда Хума (1914-1983), ${ }^{17}$ Грге Новака (1888-1978), ${ }^{18}$ Марије Илић-Агапове (1895-1984)19 и других), ${ }^{20}$ као и ликовне изложбе. У овом периоду постојао је и Француски клуб, који је због организационих проблема 1933. године спојен са Библиотеком и смештен у простор читаонице.

До почетка Другог светског рата запослени у Шабачкој народној књижници и читаоници учествовали су у оснивању сеоских књижница, којима су пружали саветодавну и помоћ у формирању књижног фонда. На основу тога може се закључити да су се у оквиру Шабачке народне књижнице и читаонице спроводиле поједине матичне функције за подручје града Шапца и околине. ${ }^{21}$ За јавне библиотеке ${ }^{22}$ биле су регулисане пре Првог светског рата, ${ }^{23}$ а чињеница да се поједине назиру у раду Шабачке народне књижнице и читаонице може да укаже на континуитет у постојању оваквог начина организовања библиотека кроз поједине облике јавног

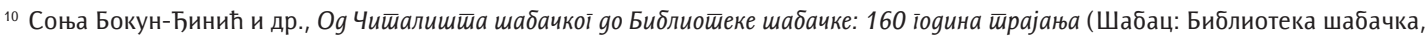
2007), 28

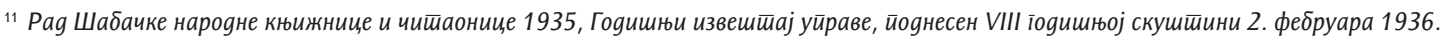
іолине (Шабац: Штамп. Драг. Милановића-Бана, 1936), http://www.digitalna.nb.rs/wb/NBS/Zavicajne_zbirke/Biblioteka_sabacka/ Zbirka_knjiga/BS_A_II_3064\#page/0/mode/1up (преузето 26.11. 2016).

12 Академик и професор универзитета у Београду.

${ }^{13}$ Књижевни, позоришни и ликовни критичар, драмски писац, песник, есејиста и преводилац.

${ }^{14}$ Филолог.

15 Професор универзитета у Београду.

${ }^{16}$ Књижевник и преводилац.

17 Друштвено-политички радник и народни херој.

18 Председник Југославенске академије знаности и умјетности, професор универзитета у Загребу.

19 Директор Библиотеке и музеја општине града Београда (данашња Библиотека града Београда) у периоду између два светска рата.

20 О појединим предавањима детаљније видети у: Pag Шабаике нароgне књижнице и иитаонице 1935-1941, 6-10, 5-9, 6-9, 5-9, 6-19, 6-8.

21 Утврђивање постојања матичних функција за остале народне књижнице и читаонице на територији Србије захтева детаљније истраживање.

22 Матичност јавних библиотека у периоду између два светска рата треба да буде предмет посебног истаживања и у овом раду неће бити посебно разматрана.

${ }^{23}$ Детаљније видети у монографији: Бранка Драгосавац, Јавне библиошеке у Србији оg 1901. gо 1918. їоgине (Панчево: Градска библиотека; Ниш: Народна библиотека „Стеван Сремац"; Неготин: Народна библиотека "Доситеј Новаковић”, 2016).
} 
библиотекарства и у периоду између два светска рата. У појединим селима су, на предлог Шабачке народне књижнице и читаонице, осниване домаћичке школе и одржавани аналфабетски течајеви.

Увидом у архивску грађу и штампане изворе потврђено је да подаци о броју корисника и прочитаних публикација углавном нису сачувани. Изузетак представља извештај библиотекара из 1933. године, ${ }^{24}$ где се наводи да је број корисника био 2678, а број прочитаних публикација 7169, што указује да су корисници просечно позајмљивљали око три публикације. У овом периоду извршена је организација библиотечке грађе по одељењима, што је допринело бољем функционисању Шабачке народне књижнице и читаонице (Библиотеке, читаонице, Новинарског одељења, Француског клуба). Картотека је била подељена по областима које су чинили: романи и приповетке, песме, омладинска књижевност, право и социологија, историја, географија и етнографија, богословија, естетика, филозофија и педагогија, медицина и природне науке, драме, разно и страна књижевност. Књиге су биле сложене по величини у три групе, а као модел је послужила градска библиотека у Љубљани. „Страна књижевност и ретка дела смештена су у засебном одељењу и дају се на читање и разгледање само у Читаоници. За сада је доста мали интерес за ове ствари, а и картотека ових дела још није сређена, што ће се учинити чим се доврши посао са библиотеком на нашем језику која је у свакодневној употреби." 25

У извештају за 1934. годину ${ }^{26}$ наводи се да установа није променила своју делатност: стварање што бољег фонда и омогућавање опште доступности публикација. Такође је требало да омогући популарисање науке путем предавања и оснивање народних књижница и читаоница у сеоским срединама. Поред тога, требало је отворити читаоницу и омогућити стварање музеја. У овој години, у оквиру Шабачке народне књижнице и читаонице, набављена су и сва до тада објављена дела домаћих писаца, али с обзиром на чињеницу да су била доста скупа, нису се издавала ван читаонице, што је довело до смањења броја корисника. На то је утицала и чињеница да су школске власти забраниле да ученици нижих разреда гимназије позајмљују књиге, док је ученицима виших разреда дозвољено да то ураде уз одобрење дежурног професора.

На основу података за период од 1928. до 1934. године, број монографских и серијских публикација не може се прецизно утврдити. Поседовала је 14.000 свезака 1935, а 1939. 25.000. У периоду од 1935. до 1939. годишње повећање је износило између две и три хиљаде наслова. У оквиру серијских публикација у периоду од 1935. до 1939. имала је од 56 до 68 наслова домаћих и страних новина и између 52 и 79 наслова часописа. Године 1940. фонд Шабачке народне књижнице и читаонице чинило је 21.765 наслова публикација у 32.000 примерака.

У оквиру Шабачке народне књижнице и читаонице била је развијена и значајна издавачка делатност, а кроз едицију Библиошеке Нароgної универзишешеа, између осталог, објављена су дела Јеле Спиридоновић-Савић (1890-1974), ${ }^{27}$ Александра Соловјева (1890-1971), ${ }^{28}$ Станислава Винавера, Јована Ђорђевића (1826-1900), ${ }^{29}$ Милоша Московљевића и других.

У кадровском смислу, за функционисање Шабачке народне књижнице и читаонице посебно је значајна делатност Живорада Жике Поповића (1895-1941), ${ }^{30}$ као библиотекара и члана Управе. Његово име, у периоду од неколико деценија након Другог светског рата, носила је Народна библиотека у Шапцу.

Године 1939. основан је Савез народних књижница и читаоница, који је требало да омогући повезивање свих народних књижница и читаоница на територији Краљевине.

\footnotetext{
${ }_{24}$ А $-66,307,521$ Народне књижнице и читаонице (документ бр. 231 од 03. августа 1933. године)

${ }^{25}$ А $-66,307,521$ Народне књижнице и читаонице.

${ }^{26}$ Исто.

27 Песникиња и драмска списатељица.

28 Професор Правног факултета Универзита у Београду у периоду између два светска рата.

${ }^{29}$ Историчар, књижевник, професор Шабачке гимназије.

${ }^{30}$ Професор гимназије у Шапцу, културни радник и публициста.
} 


\section{Савез народних књижница и читаоница}

Савез народних књижница и читаоница створен је на предлог Шабачке народне књижнице и читаонице. ${ }^{31}$ На оснивачкој скупштини закључено је да „потреба да се народне књижнице и читаонице у нашем крају удруже у једну јаку организацију, у виду Савеза, довела је нашу установу до одлуке: да се на празник првих народних просветитеља, Ћирила и Методија, сазове скуп претставника народних књижница и читаоница из Подриња. На овај састанак биле су позване и главне управе Југ. професорског друштва и Југ. учитељског удружења, као и представници културних и просветних установа у земљи, просветне власти и грађани Шапца." ${ }^{\prime 2} \mathrm{Ha}$ састанку делегата народних књижница и читаоница са представницима појединих културнопросветних друштава, који је одржан истог дана, расправљало се и о: положају и финансирању народних књижница и читаоница, њиховом односу према задругама и школама, закону о народним библиотекама и правном регулисању њиховог рада, штампарској делатности народних књижница и читаоница.

Да би Савез почео са обављањем делатности, било је потребно да се установе правила о раду и да их потврде одговарајуће управљачке структуре на нивоу општине и Краљевине, а у вези са тим вођена је и обимна преписка. Начин рада (задаци, права и обавезе чланова итд) Савеза одређен је Правилима. 33 Чланице Савеза могле су да буду све народне књижнице и читаонице.

Задаци Савеза били су: оснивање и удруживање народних књижница и читаоница из околине Шапца и Краљевине Југославије; брига о интересима чланова; вршење надзора над радом и предлагање мера за унапређење рада народних књижница и читаоница; брига о издавању и набавци књига, часописа и новина и посредовање у отварању кредита који би били искоришћени за помоћ народним књижницама и читаоницама; омогућавање размене публикација између народних књижница и читаоница и учествовање у организовању културно-просветне делатности чланова; рад на промоцији књиге и читања у местима где не постоје народне књижнице и читаонице и организација издавачке делатности.

Народне књижнице и читаонице су као чланице Савеза имале права да преко представника учествују у доношењу одлука на скупштинама; дају предлоге за рад и затраже увид у документацију о својој делатности; набављају књиге, часописе и новине; траже помоћ за функционисање и развој; посредовање у случајевима спора између управе и чланова народних књижница и читаоница. У складу са обавезама, народне књижнице и читаонице су као чланице имале дужности да: послују у складу са препорукама Савеза; редовно шаљу годишње извештаје о раду; да учествују у изради новина које је издавао Савез; да, на основу овлашћења која су имали као чланови, изабрани представници народних књижница и читаоница учествују у извршавању одлука Скупштине.

Савезом народних књижница и читаоница управљали су: Управни одбор, Надзорни одбор и Скупштина, а његов рад био је финансиран уз помоћ Краљевине, бановинских и општинских просветних власти, уплатама од појединаца и установа, средствима чланова и завештањима. Надзор над радом вршило је Министарство просвете Краљевине Југославије, које је требало

\footnotetext{
31 Записи о оснивању Савеза народних књижница и читаоница и његовим задацима документовани су обимном архивском грађом (А) - 66, 2509, 2318), а подаци о томе сачувани су и у извештају о раду Шабачке народне књижнице и читаонице за 1939. годину; Момчило Исић, „Делатност Шабачке народне књижнице и читаонице на народном просвећивању 1928-1941", Museum бр. 2 (2001): 117-145.

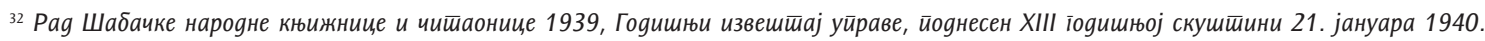
іоgине (Шабац: Штамп. Драг. Милановића-Бана, 1940), http://www.digitalna.nb.rs/wb/NBS/Zavicajne_zbirke/Biblioteka_sabacka/ Zbirka_knjiga/BS_A_II_3068\#page/0/mode/1up (преузето 26.11. 2016).

${ }^{33}$ АЈ - 66, 2509, 2318 Народне књижнице и читаонице (Су-Ти).
} 
да потврди и Правила која због почетка Априлског рата нису озваничена ${ }^{34}$ иако је спроведена процедура на нижим нивоима управљања (одобрења начелника Шабачког среза 35 и Просветног одељења $\left.{ }^{36}\right)$.

\section{Закључак}

У тексту је описана делатност (правила, број и организација) народних књижница и читаоница као облика јавног библиотекарства на територији Србије у периоду између два светска рата.

Као пример добро организоване народне књижнице и читаонице у оквиру локалне заједнице и Краљевине издвојена је Шабачка народна књижница и читаоница, а представљене су и културно-образовне делатности библиотеке, музеја и народног универзитета који су чинили њен саставни део. Значај ове установе за библиотечку делатност у периоду између два светска рата може се посматрати и кроз сарадњу са сеоским народним књижницама и читаоницама, које су, с обзиром на структуру становништва, имале велики значај у просвећивању села.

Чланови Шабачке народне књижнице и читаонице учествовали су у оснивању Савеза народних књижница и читаоница, који је у времену настанка био значајан за професионализацију делатности овог облика јавног библиотекарства. Савез је требало да координира рад свих народних књижница и читаоница на територији Краљевине. Његова правила спроводила су се у пракси, упркос чињеници да их Министарство просвете није усвојило, али су прихваћена у оквиру скупштине Савеза и на нижим нивоима управљања.

Рад читалишта и јавних библиотека, као друга два облика јавног библиотекарства у Србији међуратног периода, разматран је у обиму који је био неопходан да би се детаљније разјаснио њихов однос са народним књижницама и читаоницама. Разлика између народних књижница и читаоница и јавних библиотека описана је кроз начин финансирања и набавку публикација, док структура и обим делатности јавних библиотека у овом тексту нису били предмет истраживања. С обзиром да се, осим у имену, делатност читалишта није разликовала од народних књижница и читаоница, она нису детаљније разматрана.

Текст је заснован на детаљном истраживању грађе Архива Југославије, која се односи на рад народних књижница и читаоница и у томе представља новину. На овај начин омогућено је прецизно утврђивање броја народних књижница и читаоница које су постојале на територији Србије у периоду између два светска рата.

Публикације које се односе на делатност Шабачке народне књижнице и читаонице засноване су на грађи Међуопштинског историјског архива у Шапцу. Подаци о њеном раду могу се пронаћи и у грађи Архива Југославије. Њихово поређење омогућава допуну већ постојећих података, али и откривање до сада непознатих чињеница, на основу којих је могућ прецизнији увид у њену структуру и делатност.

Истраживање свих облика јавног библиотекарства периода између два светска рата значајно је јер представља спону са целокупним јавним библиотекарством након Другог светског рата, које је, иако у значајно промењеним друштвено-политичким условима било веома развијено. Уколико се спроведе на одговарајући начин, биће омогућено утврђивање потенцијалне везе читаоница, народних књижница и читаоница и јавних библиотека међуратног периода са народним библиотекама и читаоницама, које су својим обимом и делатношћу чиниле окосницу јавног библиотекарства послератног периода.

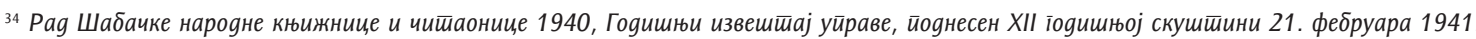
іолине (Шабац: Штамп. Драг. Милановића-Бана, 1941), http://www.digitalna.nb.rs/wb/NBS/Zavicajne zbirke/Biblioteka_sabacka/ Zbirka_knjiga/BS_A_II_3069\#page/1/mode/1up (преузето 26.11. 2016).

${ }_{35}$ АJ - 66, 2509, 2318 Народне књижнице и читаонице (Су-Ти) (документ бр. 14521 од 26. 08. 1939. године).

${ }^{36}$ АЈ - 66, 2509, 2318 Народне књижнице и читаонице (Су-Ти) (документ бр. 30255/39 од 13. 09. 1939. године).
} 
Ђурашиновић Б. „Народне књижнице и читаонице као облик јавног библиотекарства у Србији од 1918. до 1941. године”, 62-70

\section{Литература и извори:}

1. Arhiv Jugoslavije, fond Ministarstva prosvete Kraljevine Jugoslavije A - 66, 296-309 Narodne knjižnice i čitaonice; A - 66, 472, 745 Narodne knjižnice i čitaonice (B-Ž); A - 66, 2278, 2151 Narodne knjižnice i čitaonice (A-Bolj); A - 66, 2279, 2151 Narodne knjižnice i čitaonice (Бos-Go); A - 66, 2280, 2151 Narodne knjižnice i čitaonice (Gr-Kor); A - 66, 2281, 2151 Narodne knjižnice i čitaonice (Kos-L); A - 66, 2282, 2151 Narodne knjižnice i čitaonice (Lj-Pe); A - 66, 2283, 2151 Narodne knjižnice i čitaonice (Pi-Ra); A - 66, 2284, 2151 Narodne knjižnice i čitaonice (Re-Sr); A - 66, 2285, 2151 Narodne knjižnice i čitaonice (St-T); A - 66, 2286, 2151 Narodne knjižnice i čitaonice (U-V); A - 66, 2287, 2151 Narodne knjižnice i čitaonice (Z-Ž); A - 66, 2498, 2318 Narodne knjižnice i čitaonice (ABe); A - 66, 2499, 2318 Narodne knjižnice i čitaonice (Bi-C); A - 66, 2500, 2318 Narodne knjižnice i čitaonice (Č-F); A - 66, 2501, 2318 Narodne knjižnice i čitaonice (G-I); A - 66, 2502, 2318 Narodne knjižnice i čitaonice (J-Ko); A - 66, 2503, 2318 Narodne knjižnice i čitaonice (Kr-Ky); A - 66, 2504, 2318 Narodne knjižnice i čitaonice (L-Ni); A - 66, 2505, 2318 Narodne knjižnice i čitaonice (No-Pi); A - 66, 2506, 2318 Narodne knjižnice i čitaonice (Plj-Pt); A - 66, 2507, 2318 Narodne knjižnice i čitaonice (R-Sm); A - 66, 2508, 2318 Narodne knjižnice i čitaonice (So-St); A - 66, 2509, 2318 Narodne knjižnice i čitaonice (Su-Ti); A - 66, 2510, 2318 Narodne knjižnice i čitaonice (To-U); A - 66, 2511, 2318 Narodne knjižnice i čitaonice (Va-Vlad); A - 66, 2512, 2318 Narodne knjižnice i čitaonice (Vlas-Ž); A - 66, 262, 503 Zbornik raspisa Ministarstva prosvete o radu na narodnom prosvećivanju i Pravila narodnih knjižnica i čitaonica.

2. Bokun-Đinić, Sonja, Nada Radovanović i Vesna Adamović. Od Čitališta šabačkog do Biblioteke šabačke: 160 godina trajanja. Šabac: Biblioteka šabačka, 2007.

3. Dragosavac, Branka. Javne biblioteke u Srbiji od 1901. do 1918. godine. Pančevo: Gradska biblioteka; Niš: Narodna biblioteka "Stevan Sremac"; Negotin: Narodna biblioteka "Dositej Novaković", 2016.

4. Isić, Momčilo. „Delatnost Šabačke narodne knjižnice i čitaonice na narodnom prosvećivanju 19281941", Museum br. 2 (2001): 117-145.

5. Rad Šabačke narodne knjižnice i čitaonice 1935, Godišnji izveštaj uprave, podnesen VII godišnjoj skupštini 2. februara 1936. godine. Šabac: Štamp. Drag. Milanović-Bana, 1936. http://www.digitalna.nb.rs/wb/NBS/ Zavicajne_zbirke/Biblioteka_sabacka/Zbirka_knjiga/BS_A_II_3064\#page/0/mode/1up (preuzeto 26. 11. 2016).

6. Rad Šabačke narodne knjižnice i čitaonice 1936, Godišnji izveštaj uprave podnesen IX godišnjoj skupštini 17. januara 1937. godine. Šabac: Štamp. Drag. Milanović-Bana, 1937. http://www.digitalna.nb.rs/wb/NBS/ Zavicajne_zbirke/Biblioteka_sabacka/Zbirka_knjiga/BS_A_II_3065\#page/0/mode/1up (preuzeto 26. 11. 2016).

7. Rad Šabačke narodne knjižnice i čitaonice 1937, Godišnji izveštaj uprave podnesen X godišnjoj skupštini 16. januara 1938. godine. Šabac: Štamp. Drag. Milanović-Bana, 1937. http://www.digitalna.nb.rs/wb/NBS/ Zavicajne_zbirke/Biblioteka_sabacka/Zbirka_knjiga/BS_A_II_3066\#page/0/mode/1up (preuzeto 26. 11. 2016).

8. Rad Šabačke narodne knjižnice i čitaonice 1938, Godišnji izveštaj uprave podnesen XI godišnjoj skupštini 5. februara 1939. godine. Šabac: Štamp. Drag. Milanović-Bana, 1939. http://www.digitalna.nb.rs/wb/NBS/ Zavicajne_zbirke/Biblioteka_sabacka/Zbirka_knjiga/BS_A_II_3067\#page/0/mode/1up (preuzeto 26. 11. 2016).

9. Rad Šabačke narodne knjižnice i čitaonice 1939, Godišnji izveštaj uprave podnesen XII godišnjoj skupštini 21. januara 1940. godine. Šabac: Štamp. Drag. Milanović-Bana, 1940. http://www.digitalna.nb.rs/wb/NBS/ Zavicajne_zbirke/Biblioteka_sabacka/Zbirka_knjiga/BS_A_II_3068\#page/0/mode/1up (preuzeto 26. 11. 2016).

10. Rad Šabačke narodne knjižnice i čitaonice 1940, Godišnji izveštaj uprave podnesen XIII godišnjoj skupštini 21. februara 1941. godine. Šabac: Štamp. Drag. Milanović-Bana, 1941. http://www.digitalna.nb.rs/wb/NBS/ Zavicajne_zbirke/Biblioteka_sabacka/Zbirka_knjiga/BS_A_II_3069\#page/1/mode/1up (preuzeto 26. 11. 2016). 
Ђурашиновић Б. „Народне књижнице и читаонице као облик јавног библиотекарства у Србији од 1918. до 1941. године”, 62-70

11. Stamatović, Desanka. Čitališta u Srbiji u XIX veku. Pančevo: Gradska biblioteka, 2011

12. Stefanović, Mila. Jagodinsko bibliotekarstvo (1851-2011). Jagodina: Narodna biblioteka "Radislav Nikčević", 2011.

13. Vučković, Željko. Javne biblioteke i javno znanje. Novi Sad: Biblioteka Matice srpske; Futura publikacija, 2003.

\title{
Social Libraries with Reading Rooms as a Form of Public Librarianship in Serbia from 1918 to 1941
}

\begin{abstract}
This paper gives an overview of work of social libraries with reading rooms in Serbia from 1918 to 1941. Its introductory part describes the forms of public librarianship in Serbia in the interwar period, with a special emphasis on the differences between the types of institutions. Special attention is paid to connections between social libraries and public libraries. The first part of the paper is dedicated to definition, regulations and functioning of social libraries with reading rooms, as a form of public librarianship. The second part deals with work of the Šabac Social Library with a Reading Room, which worked from 1928 to 1941, as the best organized institution of this type in Serbia in the interwar period. The last section describes forming of the Union of Social Libraries with Reading Rooms, an organization that was supposed to bring together all social libraries with reading rooms in the territory of the Kingdom, and defines its scope of work.
\end{abstract}

Keywords: social libraries with reading rooms, public libraries, social libraries, rules of social libraries with reading rooms, Šabac Social Library with a Reading Room, public librarianship, Serbia 1918-1941, Union of Social Libraries with Reading Rooms 